\title{
The Lessons of Charlie, or Locality in the Age of Globalization
}

\section{Fabienne Darling-Wolf}

School of Media and Communication, Temple University, 1801 N Broad St, Philadelphia, PA 19122, United States

\section{Introduction}

I was returning to London from a short vacation in the French town where I grew up when the social media exploded. I did not have time to figure out what was going on before losing my signal as our train entered the Eurotunnel. When we emerged from the Channel the "Je suis Charlie" hashtag was well on its way to becoming one of the most popular in the history of Twitter. Two days later, 19 people (including two terrorists) were dead and I found myself struggling to wrap my head around the fact that $\mathrm{Cabu}$ - the man my generation probably best remembers for his live sketching in Récré A2-would never again draw his Grand Duduche, or Dorothée's nose, for that matter. Of course, I did not know at the time that by the end of the year, an even more deadly attack would have shaken the country. In hindsight, the attacks on Charlie Hebdo's Paris headquarters and the following acts of terrorism targeting the Jewish community in the early days of January 2015 were just the beginning of a new era in France's relationship to the global.

Making sense of terrorism is never an easy task. On the most obvious level, the 2015 attacks in Paris or Beirut point to the most dangerous undertows of power struggles that globalization scholars of varied theoretical convictions have long discussed in their work [1-3]. In order to fully comprehend their significance, however, these tragic events must also be considered in relationship to more complex webs of shifting and contested identities and their "on the ground" definitions-in relationship, in other words, to processes through which "global convergences ... still take their force from configurations of value, ethics, and religion that are strikingly local and variable" [2]. Because it targeted specific individuals engaged in a debate about (among other things) value, ethics, and religion at both the local and the global level, the attack on Charlie Hebdo provides a powerful terrain on which to tease out this complexity.

Drawing from reactions to the attack in the French press and in social media and in an effort to give some measure of meaning to the deaths of its victims-this paper explores the lessons to be drawn from this tragedy. What can the events at Charlie Hebdo teach us, theoretically, about the relationship between globality and locality? What do they tell us about the "imaginaries within which [globalization] operates and the interculturality that it mobilizes?" What can we learn about the role of the media in shaping these imaginaries? What, in turn, can these theoretical musings teach us about the theory and practice of politically engaged journalism under conditions of globalization?

\section{The Deadly Consequences of Globality}

The concept of globalization has generated much anxiety among scholars and popular thinkers alike $[3,4,5]$. While they may not be symptomatic of a clash of civilizations as described by Huntington, it is clear that the events at Charlie Hebdo intersect with processes of identity formation profoundly shaped by the fact that, today, "global cultural flows, whether religious, political, or market-produced, have entered into the manufacture of subjectivities" [2]. The jihadist zeal of perpetrators Chérif and Saïd Kouachi was fueled by global networks of Al Qaeda affiliates, who trained the brothers and financed their

\section{Publication History:}

Received: March 07, 2016

Accepted: May 21, 2016

Published: May 23, 2016

\section{Keywords:}

Charlie Hebdo, Globalization, jihadism, Communication technologies

activities. Djamel Beghal, the "mentor" Chérif met in a French prison, was dispatched to France after spending some time in one of Osama bin Laden's camps in Afghanistan. On the day of the shootings, a group affiliated with Al Qaeda in Yemen claimed responsibility for the attack on the satirical newspaper. Amedy Coulibali, who perpetrated the attack on the Porte de Vincennes kosher supermarket, bought his weapons in Belgium. Chérif learned to manipulate a virtual AK-47 online [6].

While acts of terrorism certainly took place before globalization became a favorite buzzword, the scope and speed of global exchange and the transformations in the nature of individuals' experience of space and time that most scholars agree is characteristic of our contemporary era $[7,8,9]$, have taken the problem to new heights. On the most practical level, the intensified speed and scale of global flows of information and individuals under conditions of globalization facilitate the organization of transnational networks of influence and action, including-but certainly not limited to-ones preaching jihadism. While various governments have proven that digital technology can certainly be monitored, the sheer amount of information distributed and the pace at which it is spread exceed the capacities of most antiterrorist units.

On a broader level, the transformations in individuals' social space, in the interrelated imagination of both the "global" and the "local" brought about by globalization exacerbate anxieties and uncertainties. The perceived loss of national sovereignty and threats of cultural invasion that accompanies our increased "consciousness of the world as a whole" [10] contributes to a situation in which "new incentives for cultural purification" emerge as "violence itself is one of the ways in which the illusion of fixed and charged identities is produced, partly to allay the uncertainties about identity that global flows invariably produce" [2]. In other words, not only is global terrorism aided by the increased efficiency and availability of transcultural communication and exchange, but processes of globalization also foster an environment in which feelings of displacement and anger that may lead to violence are more likely to occur.

*Corresponding Author: Dr. Fabienne Darling-Wolf, School of Media and Communication, Temple University, 1801 N Broad St, Philadelphia, PA 19122, United States, E-mail: fdarling@temple.edu

Citation: Darling-Wolf F (2016) The Lessons of Charlie, or Locality in the Age of Globalization. Int J Journalism Mass Comm 3: 115. doi: http://dx.doi. org/10.15344/2349-2635/2016/115

Copyright: (c) 2016 Darling-Wolf. This is an open-access article distributed under the terms of the Creative Commons Attribution License, which permits unrestricted use, distribution, and reproduction in any medium, provided the original author and source are credited. 
Because of their far-reaching global repercussions but specific targets, the tragic events of January 2015 in France provide a unique opportunity to explore these local/global connections. The extensive coverage found in the digital version of the French newspaper Le Monde was taken as a starting point here to enter the conversation. The newspaper published more than 250 articles mentioning Charlie Hebdo between January 7, the day of the attacks on the satirical newspaper and the end of May 2015. Out of these 250 stories, 241 articles dealt with Charlie in a substantial manner and were selected for further analysis. In addition to this coverage, however, the digital version of Le Monde was chosen for its important role as an aggregator of videos and discussions taking place throughout the French media landscape. Le Monde has also historically served as a terrain for intellectuals and officials and in this case, the high profile survivors of the attacks to express their views. In other words, the legacy newspaper's website is the go-to place if one wishes to get a sense of the tenor of public discourse in France at any point in time. It is in this spirit that this paper explored the coverage. While themes were identified through a textual analysis, these themes will not be addressed in detail here. Rather, the coverage-and the broader conversation about the events taking place in the French cultural context and elsewhere-will serve as a starting point to explore the theoretical implications of these events and the practical lessons to be learned.

\section{A Global Conversation}

The Kouachi brothers were not the only individuals connected to the Charlie Hebdo tragedy to be involved in networks of transcultural exchange or in the process of negotiating their position within the global imagination. For years before the attack, the murdered cartoonists had been engaged in a global conversation about world religions including, but not limited to, Islam. In early 2006, Charlie Hebdo was among the first of a handful of publications to reproduce Kurt Westergaard's highly controversial cartoons of the Prophet Muhammad, which had set off a worldwide wave of controversy and violent protests as well as attacks on the cartoons' author when they were initially published in the Danish newspaper Jyllands-Posten $[11,12]$. In 2011, Charlie reignited the controversy by publishing a special edition titled "Charia Hebdo" that prompted an attack on its offices that left them burnt to the ground. In a dark foreboding of what was to come, its cover featured Muhammad saying, "100 lashes if you don't die laughing" [13]. In 2013, Stéphane Charbonnier (aka Charb) and Zineb El Rhazoui authored a series of comic books titled "Muhammad's life."The radical leftist weekly generally made it a point to assert its anti-clerical stance "Attacking all religions, that's our identity," explained its editor in chief [14] and Charlie's cartoonists were clearly aware of the dangers associated with this position. Three years before the attack that would claim his life, Charb noted, "I went through 20 body guards in one year. ... It may sound a little pompous, but I'd rather die standing that live on my knees" [14].

The newspaper chose to continue to engage in this global conversation with its first edition after the attack, whose cover featured a crying Muhammad holding a "Je suis Charlie" sign under the heading "all is forgiven," putting publications across the globe in the difficult position of having to decide whether or not to reproduce the image and sparking protests in Pakistan, Qatar, Senegal, Egypt, Jordan, Mauritania, and Algeria, to name a few $[15,16]$. In an AFP video released shortly before its publication, cartoonist Rénald Luzier (aka Luz) commented on the terrorists' lack of humor and perspective "Terrorists were kids once, they drew cartoons. Like us. Like all children. So there is a moment when they lost their sense ofhumor ... when they lost their ability to see things from a distance" and concluded "I'm sorry, we drew him again" [17]. Individuals all across Europe rushed to buy this "numéro des survivants" (survivors' edition) which eventually ended up selling eight million copies globally, some of them costing more than $\$ 1000$ on eBay [18] quite a far cry from its typical fewer than 30,000 copies weekly sales. The special issue's inside pages featured two drawings that Laurent Sourisseau (aka Riss) - another survivor of the attack produced with his left hand shortly after leaving the hospital. One showed a cartoonist toiling at his desk, the other a terrorist shooting three victims with a machine gun. The caption read: "Charlie Hebdo cartoonist, 25 years of hard work. Terrorist, 25 seconds of work. Terrorism: a job for lazyasses" [19].

The attack itself sent shockwaves throughout the world that reached far beyond those previously familiar with the satirical newspaper. Often compared in the press to the events of September 11, 2001 in New York $[20,21]$ it sparked responses from governments across the globe. Vladimir Putin, David Cameron, Angela Merkel, and Shinzo Abe expressed their support and solidarity. Barak Obama offered help bringing the terrorists to justice [22]. On January 11, officials from six different continents participated in a "historical" march in Paris. Hundreds of spontaneous manifestations were organized throughout France [23], Europe [24], Latin American and the United States $[20,21]$. "Je suis Charlie" signs appeared in the streets of London, Lima, Tirana, and in the Golden Globe Awards [25,26]. Even those critical of the newspaper found themselves in the difficult position of having to condemn the attacks while simultaneously denouncing the work of its celebrated cartoonists [16].

In his "short introduction" to theories of globalization, Manfred Steger defines globality as "a social condition characterized by tight global economic, political, cultural, and environmental interconnections and flows" (p. 9, emphasis in original). If on the eve of 9/11, Le Monde had declared that "nous sommes tous américains" [27], in January 2015 the whole world seemed to be forced to decide whether or not they were "Charlie." As if often the case in times of great tragedy, the world seemed, for a brief moment, to fulfill McLuhan's (1964) prophesy of a "global village". It was, in other words, a moment during which the awareness of the global that theorists agree is one of the defining characteristics of contemporary globalization $[28,29,30]$ was particularly heightened.

\section{An Imagined Globality}

The above discussion starts to make apparent the importance of the role played by the media in feeding and shaping individuals' engagement with "the global" which, of course, is also the central tenant of McLuhan's (in)famous motto. Under conditions of globalization, individuals envision "the global" through their engagement with flows of cultural products, images and information increasingly disconnected from their place of origin $[8,31,32]$. This "deterritorialization" of cultural life results in a globality that is envisioned and imagined largely-through but certainly not limited to individuals' engagement with "mediascapes" that provide the scripts and narratives through which "imagined worlds that are chimerical, aesthetic, even fantastic objects” are constructed [28]. As cultural critic Néstor García Canclini (2014) concludes, if Benedict Anderson called nations "imagined communities", [29] then it is "even more pertinent to call globalization imagined” (p. 42).

This dimension of globalization, which requires us to situate "questions of culture, subjectivity and everyday life ... against the 
Page 3 of 7

ubiquitous presence and proliferation of communication technologies and their ability to transcend time and space" [34], was immediately evident in the aftermath of the Charlie Hebdo attacks. On January 8, Twitter France announced that the "Je suis Charlie" hashtag had already generated 3.4 million messages of solidarity-a rate of nearly 6,500 tweets per minutes-at the end of the day [35]. More than 5 million tweets would eventually be sent using the hashtag. "Je suis Charlie" signs were simultaneously appearing in the physical landscape of individuals' throughout the world such as, for instance, in the window of the Waitrose across from my place of employment at the time in London's posh South Kensington neighborhood, home to the Lycée Charles de Gaulle and much of the upper-class French expat community. The hashtags \#JeSuisFlic, \#JeSuisAhmed and \#JeSuisFrank were also widely used as expressions of support for the two police officers killed during the attack while \#JeNeSuisPasCharlie had already generated nearly 15,000 tweets on January 8 [36]. The social media were more broadly used as an immediate avenue for a global wave of reactions [37].

It is worth further noting that the killings at Charlie Hebdo might have never taken place without the medias ability to spread images across cultural boundaries. As mentioned, Charlie Hebdo's journalists were engaged in a global discussion on a number of social issuesincluding freedom of expression-through the medium of their satirical cartoons. As international journalist Patrick Chappatte who works for the international edition of the New York Times as well as the Swiss newspaper Le Temps and the Sunday edition of the German Neue Zürcher Zeitung put it in an interview in Le Monde, "what we draw today in any corner of Europe ... can now be seen in the streets of Karachi, Lagos, or Jakarta” [38]. Just how global this discussion is became evident after the attack in the numerous expressions of shock and support from cartoonists hailing from such diverse places as Iran, Argentina, the United States and Italy [39]. The cartoons they produced in response often, in turn, referenced other "global" crises such as, for instance, that of Israeli cartoonist Kichka featuring two pencils standing like the World Trade Center twin towers about to get hit by a flying machine gun [39].

As mentioned, the mainstream media which, of course, also heavily reported every moment of the tragic events from every corner of the world were eventually dragged into the cartoonists' broader conversation by Charlie Hebdo's controversial "une" featuring a crying Muhammad in its first issue after the attack. News outlets across the globe were faced with the decision of whether or not to republish the drawing as governments across the Middle East and Africa condemned the satirical newspaper's latest offense [40]. In turn, the French press feverishly reported foreign governments' and global publications' every move $[16,20,41]$, shaping, in the process, French audiences' imagination of their society's position in relationship to "the global". In fact, this type of reporting on Charlie's global implications was the most frequently recurring theme (with 65 articles solely focused on the subject) in Le Monde's coverage.

Ultimately, the range of reactions to the image (and interpretations of Charlie Hebdo's gesture), point not only to the highly global scale of social and mass mediated debates and to the increasing speed at which they develop, but also to the fragmented nature of the global imagination. As Chappatte concluded in a comment on leading US newspapers' decision not to publish the cartoon:

Even within the West, it is surprising to see the differences between the perception of the francophone world, which is my culture of origin, and the United States where I live. Many people across the Atlantic do not understand the corrosive spirit and second degree of Charlie's drawings. I don't think we'll ever reach an agreement on a global humor, common on a planetary scale. Maybe this is the first conflict of globalization, and it's a cultural conflict [38].

\section{From Globality to locality, or Charlie Hebdo in context}

The tragic events that took place in and around Paris in early January 2015 and, more generally, the way in which both the murdered cartoonists and their killers envisioned their work powerfully illustrate the extent to which individuals' social imagination is shaped by processes of transcultural exchange (for better or for worse) under conditions of globalization. They also illustrate, however, the diversity of "globalized imaginaries" that emerge through such processes. If the metaphor of the global village "brings expectations of an extensive, unitary community, with a corresponding set of universal, global values" [42], globalization theorists understand that if local community can be transcended "its articulation with the global is imagined in diverse ways" even within parts of the world generally conceived as relatively culturally connected.

This suggests that ascertaining the lessons to be drawn from the Charlie Hebdo tragedy requires us to more carefully connect it to the specific socio-cultural context(s) in which it took place, not in an effort to oppose the "local" to the "global", but in an effort to better understand their fundamental interconnection or, as Appadurai [43] puts it, to explore how the increased complexity of global cultural flows has affected the production of "localities" that are not "subordinate instances of the global, but in fact the main evidence of its reality".

A closer look at the position of the satirical newspaper in the French cultural context and at the discussions that took place throughout the French mediascape in the after math of the attacks reveal dimensions of the global/national/local nexus often missed by commentators in the United States, and point to the multidimensional nature of the production of localities constructed "against the backdrop of what we imagine about others".

For instance, Charlie Hebdo's significance cannot be adequately understood without taking into account the historical role of the satirical press in France or what commentator Karima Bennoune [44] described on the one-year anniversary of the murders as "committed anti-racism and solidarity, even if it comes in the shape of a merciless, sometimes disturbing French satirical tradition not always well understood elsewhere like Mad Magazine with politics". Charlie was born in 1970 from the ashes of Hara Kiri, the highly caustic satirical magazine that rocked Gaullist France and was periodically banned by its government throughout the 1960s [45]. It is a newspaper of "soixantehuitards", the generation of radical leftist militants and intellectuals involved in the May 1968 barely-missed revolution. Its work must be considered in relationship to the continuing presence and influence of satirical newspapers (e.g. Le Canard Enchaîné, founded in 1915) and, more generally, in the context of the highly politically engaged nature of segments of the French press (e.g. the communist L'Humanité, published since 1905). In fact, Charlie Hebdo's "edition des survivants" was developed in the offices of another post-68 leftist newspaper Libération-founded by Jean-Paul Sartre in the early 1970s thatwelcomes the Charlie cartoonists whenever their safety is threatened (as when their offices were bombed in 2011). In a socio-political environment lacking the protection of an equivalent to a U.S.-style first amendment, such publications are often seen as a central even if frequently offensive custodians of freedom of expression. This fact became quickly apparent in the extent to which the media coverage of the killings, both in France and elsewhere, focused on this issue. 
Its impact must also be connected to the broader popularity of Franco-Belgian Bandes dessinées-or BD (pronounced bé-dé) for short-throughout Europe (and many former colonies) and particularly in Francophone contexts where virtually everyone grows up reading Tintin, Astérix, or The Smurfs. The controversy surrounding whether or not the Angoulême International Comics festival should have exceptionally presented its Grand Prize, normally honoring the work of a single individual, to the satirical newspaper in its late January edition illustrated the connections between these two cultures. So did the numerous cartoons published throughout the world in reaction to the killings and in memory of its lost cartoonists, and the collective tribute album published by a group of 20 or so BD publishers. As one of them put it, "We were all tied in some way to the history of Charlie Hebdo. Cabu and Wolinski marked all generations of bandes dessinées authors. We had to do something" [46]. The festival eventually opted to create a special "freedom of expression prize" to honor Charlie Hebdo-the Japanese Katsuhiro Otomo (creator of Akira) was awarded to Grand Prize-and hosted countless events to commemorate the work of its lost cartoonists.

It is also important to note the cultural significance not only of Charlie Hebdo itself, but, more generally, of its murdered cartoonists. Charb, Wolinski, Honoré, Tignous and Cabu, in particular, were celebrated figures throughout the French popular cultural scene whose influence extended far beyond their work for the satirical newspaper. Cabu, for instance, worked for a number of other French publications ranging from the conservative Le Figaro to the leftist Canard Enchaîné. In addition to his live sketching on the highly influential children's program Récré A2, he was known along with Wolinski for his weekly commentary on the political talk show Droit de Résponse, a show that would also give the younger Charb its first exposure as a cartoonist. All published extensively. The characters they drew were part of the fabric of France's visual culture. The fact that these individuals are referred to by their pen names throughout the press coverage of the-attacks they are simply Charb, Wolinski, Honoré, Tignous, and Caburather than Stéphane Charbonnier, George Wolinski, Phillipe Honoré, Bernard Verlhac or Jean Cabut-illustrate the level of familiarity they enjoyed.

Regardless of their position toward the satirical newspaper, many mourned the loss of these "symbols of French culture." "They killed Cabu!" was a common reaction throughout France on the day of the tragedy [47]. As a 66-year old teacher explained in a Le Monde interview, "People of my generation can't believe it. What happened is impossible to imagine. I discovered Cabu in the early 1970s" [48]. "I cried as if a family member had died", commented an attendee at a commemorative march on January 8, "Who's going to make us laugh?" wondered another $[47,49,50]$."Indeed, who's going to make us laugh?" continued the Le Monde article, "since Cabu, Wolinksi, Charb, Tignous and the other are gone?". Thus, the attack on the satirical newspaper was not only an attack on a certain political position or even, as many pointed out, on freedom of expression, it was an attack on a certain version of "Frenchness". As Karim, a business owner in his 40s whom Le Monde identified as a "non practicing Muslim" put it, "We've known the slain cartoonists since we were children.... I never felt more French. It's the first time in my life I sang the Marseillaise" [51].

Not everyone, however, felt represented in this vision. The media coverage made much of the fact that members of the immigrant community often did not pledge allegiance to the satirical newspaperthey were "not Charlies" [52-55]. But Charlie Hebdo's relationship to the larger French cultural context had long been difficult and those who expressed grief over the lost of the slain cartoonists were not necessarily supporters of their work. As El Rhazoui, Charb's collaborator and survivor of the attack, put it, "I wish those who died had benefited from such support while alive. And this was not at all the case". In the course of its history, the newspaper has been the target of numerous lawsuits and attacks particularly from the far right of the political spectrum and religious organization, but also sometimes hailing from members of the radical left. In 1982, it ran out of money and stopped publishing for 10 years. Shortly before the attacks brought a sudden influx of funds in the form of increased sales and spontaneous donations, the entirely reader-supported newspaper was again in such dire financial trouble that its editorial team had to take a salary cut. In November 2014, it had issued a call for donations in Le Monde and other media. Charb, its director of publication, spent so much time searching for sources of revenue that he said it "felt like prostitution" [56]. The recent influx of funds has resulted in new tensions and controversies [57-59]. In May 2015, Luz announced that he would leave the newspaper [60], followed by columnist Patrick Pelloux in September of the same year [61].

Perhaps the most debated dimension of Charlie's work both locally and globally has been the newspaper's relationship to Islam and, consequently, to the related question of race relations in France. While a detailed engagement with this complicated and multilayered issue is beyond the scope of this paper, a few points are worth outlining here. First, Charlie's stated mission to attack "the taboo of religion" until criticizing Islam becomes "as banal as [criticizing] Catholicism" [14] must be seen in the context of France's strongly asserted secular national identity where "the laws refer to individuals as universal citizens, linked to the secular nation-state" and understood in relationship to this stated ideal's impact on race relations. France's official position is one of "color blindness" where "[a]ny recognition of ethnic particularity is presumed to dilute the force of the transcendental principle of 'equality before the law"' [62]. Thus, as García Canclini explains [63], "In the West, nations found different arrangements for living multiculturally. France and other European countries subordinated the differences to the secular ideas of the republic" (p. 78).

The fact that France's position on color blindness is more official rhetoric than reality was, however, clearly illustrated by the intensity of debates surrounding the issue in both the mainstream and social media in the aftermath of the Charlie attacks. Representatives of the French Islamic community found themselves in the difficult position of having to uphold this ideal while pointing to its less-than-perfect application-as when President of the Union des Organizations Islamiques de France Amar Lasfar declared that he is "Muslim in the mosque and secular in the street", to which lawyer Hakim Chergui responded "I was born [French], and through this birth I was given rights. What we are asking is for these rights to be respected" [64]. They walked a fine line between criticizing Charlie Hebdo's representations, supporting freedom of expression, condemning the attacks and all forms of violence, and expressing sorrow and respect for the slain cartoonists-as Chergui put it, "[W]e were placed in an ideological impasse. We did not have anyone to speak for us and say: 'I am not Charlie, but I am with Charlie"' [64]. Whether focused on the attack's possible political ramifications, [51,65], on the risks of stigmatization of French Muslims [66,67], or obsessing over who is and is not "Charlie" $[52,68]$, discussions of the "après Charlie" were imbued with the realization that subordinating multiculturalism to secularism is not an easy task. Nor did everyone agree that it is necessarily one worth pursuing-commentator Henri Astier spoke of 
"the civil war on the French Left between secularist traditionalists and multiculturalists". Even Prime Minister Manuel Valls suggested that France must "rethink, reinforce, and re-legitimize citizenship", since the concept of integration has "lost its meaning" [69].

Ultimately, it is the lack of attention to one final and crucial context, however, that prevented discussions of the attacks from becoming more fully productive: the legacy of French colonialism and its accompanying history of Orientalism. The theoretical implications of this rather major oversight will be further discussed in the next section, but suffice it to say here that regardless of their creators' intentions, Charlie Hebdo's cartoons must be considered in relationship to the long history of Orientalist visual representations of the "Other" throughout the French media [70-72]. Examples abound, but perhaps the most relevant come from the very culture in which Charlie Hebdo is most ostensibly embedded-that of FrancoBelgian bandes dessinées. Hergés-highly popular Tintin has, for instance, been vastly criticized for its colonialist undertones as its hero travels through Africa, the Middle East, Latin American, and even to the moon, and for its visual representations of non-European characters $[73,74]$. In an analysis of Tintin in the Congo (the title speaks for itself), Dunnett [75] suggests that Hergé whose works were published between 1929 and 1976 portrayed "a positive, more modern form of colonialism, which was nevertheless saturated with stark representations of colonial superiority" (p. 590). He concludes that the entire Tintin series "provides a window on a geographical imagination that has a discourse of European idealism at its core" (p. 595). The most recent Astérix, titled Cesar's Papyrus and published in 2015, was similarly attacked for continuing to represent black characters in "a classic neocolonialist tradition, similar to that of Hergé in Tintin in the Congo" [76]. As García Canclini reminds us [63], "The role that the imaginary plays in the cultural is evident, but it is an intercultural imaginary, not a mere supplement of what each local culture represents of what is lived in a given society" (p. 39). Drawing the lessons of Charlie requires us to take into account all dimensions of this intercultural imaginary, even the ones we would rather forget.

\section{The (theoretical) Lessons of Charlie}

The discussion above points to the complex and political nature of all media discourse in our increasingly globalized era. What can be learned from this (admittedly partial) case study extends beyond the questions of freedom of expression and audience sensitivities that dominated much of the discussion, especially in the United States, in the aftermath of the Charlie Hebdo attack. Certainly, questions about the extent and limits of what can/should be said were, and remain, relevant. Equally important, however, are questions of who can speak and in what context(s) [77]. Charlie Hebdo's cartoonists were wellintentioned individuals who came from a long tradition of anarchist anti-racist satirical speech that, in many ways, is historically and culturally specific to the French context. They certainly did not deserve to die. However, they along with most commentators reflecting on their work, failed to critically consider the implications of their own identities and position as celebrated figures on the French intellectual scene. Nor were they able to relate their own cultural production to the even longer historical and cultural legacy of French imperialism. As Linda Alcoff [78], Rey Chow [79], bell hooks [80], Gayatri Spivak [81] and others too numerous to mention remind us, speaking for others is never an easy task, especially when coming from a position of privilege. While aware of participating in a global conversation, Charlie's slain leaders were also trapped in the local politics of aprevious era "...local politics of a previous era, those of a vastly white- male dominated radical leftist movement that prevented them..." prevented them from understanding how their work might resonate differently with different dimensions of France's contemporary global imaginary. Like the cultural critics who were "called to task for their unself-conscious production of cultural representation" [82] during the crisis of representation that shook anthropology and cultural studies in the 1980s and 90s, they did not see their complicity with colonialist discourse.

Thus, what was most crucially missing, both from the cartoonists' perspective and from the heated debates about what was to become of France in the "après Charlie"-and one might unfortunately now add the post-November 2015 attacks - was a robust discussion of the "avant Charlie" of France's colonialist past and of its history of orientalist imagery. Tackling this context's impact on the interrelated formation of the global imagination and of individuals' sense of locality might have helped commentators understand why representing the Prophet Mohammed even as a way to test the limits of freedom of expression is not the same as representing the Pope. What prevents criticizing Islam from becoming "as banal as [criticizing] Catholicism" [14] is the fact that criticizing from a position of privilege is not the same as criticizing from a position of subordination.

Ultimately, the Charlie Hebdo tragedy and the intense discussions it generated illustrate the extent to which the local and the global are mutually constituted under conditions of globalization. As García Canclini concludes [63], "we represent and constitute with images what happened to our society in relation to others because the territorial relations with what is one's own are traversed by links to those who reside in other territories" (p. 39). It also illustrates, however, how contemporary flows of cultural politics can produce different versions of both globality and locality as "[D]ifferent forms circulate through different trajectories, generate diverse interpretations, and yield different and uneven geographies" [2]. This means that social criticism must to be attuned to the global/local nexus, as journalists including satirical ones are always involved in its production.

\section{Notes}

One of the cartoonists killed on the morning of the attacks on Charlie Hebdo, Jean Cabu simply known in France by his pen name Cabu also appeared on the highly popular children's program Récré A2 from 1978 to 1987 along with Dorothée, the show's main animator. One of the Cabu's running jokes on the show targeted Dorothées nose deemed to long which he immortalized in an 1986 book of his drawings of the animator appropriately titled Dorothée's nose.

These themes included, in order of importance: "the global" (65 articles) dealing with global reactions to and global implications of the attacks; "the après Charlie" (57 articles) dealing with the implications of the attacks on the French socio-cultural context and political scene; "the cultural context" (54 articles) more broadly linking the Charlie Hebdo controversy to various dimensions of French culture, including the culture of Bandes dessinées; "Freedom of expression" (35 articles); "Islam and other religions" (25 articles); "Je suis Charlie" (16 articles) specifically discussing the social media movement. Finally, 15 articles described the actual attacks as well as previous attacks on Charlie Hebdo's headquarters. (As the numbers indicate, 11 articles were classified in more than one category as they dealt substantially with two of these major themes).

With the exception of Zineb El Rhazoui who survived the attacks and slain copy editor Mustapha Ourrad, Charlie Hebdo's team of 
writers and cartoonists has historically been dominated by white males.

For an interesting relatively more recent analysis of the evolution of this debate see Morris [83].

\section{Refernces}

1. Appadurai A (2006) Fear of small numbers: An essay on the geography of anger. Durham, NC: Duke University Press.

2. Appadurai A (2013) The future as cultural fact: Essays on the global condition. New York, NY: Verso.

3. Huntington S (1996) The clash of civilizations and the remaking of world order. New York: Touchstone.

4. Artus P, Virard MP (2008) Globalisation, le pire est à venir [Globalization, the worst is to come]. Paris, France: La Découverte.

5. Stiglitz J (1999) Globalization and its discontents. London: Penguin.

6. Callimachi R, Yardley J (2015) From amateur to ruthless jihadist in France. The New York Times.

7. Castells M (2003) The power of identity: The information age: Economy, society and culture. Oxford, UK: Oxford University Press.

8. Giddens A (1990). The consequences of modernity. Cambridge, MA: Polity

9. Held D, McGrew A (2007) Globalization/Anti-globalization: Beyond the great divide. Cambridge, MA: Polity.

10. Robertson R (1992) Globalization: Social theory and global culture. London: Sage.

11. Smith G, Fisher I (2006) Temperatures rise over cartoons mocking Muhammad. The New York Times.

12. Truc O (2015) En 2005, l'affaire des caricatures de Mohamet au Danemark et la solidarité de "Charlie Hebdo ». [In 2005, the affair of the Muhammad caricatures in Denmark and Charlie Hebdo's solidarity]. Le Monde.

13. Bordenave $\mathrm{Y}$, Ternisien $\mathrm{X}$ (2011) Un incendie d'origine criminelle ravage les locaux de "Charlie Hebdo ». [A fire of criminal origin destroys Charlie Hebdo's offices]. Le Monde.

14. Ternisien X (2012) A « Charlie Hebdo », on n'a « pas l'impression d'égorger quelqu'un avec un feutre ». [At Charlie Hebdo we don't "have the impression to slay someone with a marker"]. Le Monde.

15. Akef $A(2015)$ Manifestations à Alger contre l'offense faite au Prophète par "Charlie Hebdo. » [Protest in Algiers again the offense done to the Prophet by Charlie Hedbo.] Le Monde.

16. Jégo M, Akef A, Bozonnet C, Barthes B (2015) « Charlie » agite de nouveau le monde arabe. ["Charlie" agitates the Arab world again]. Le Monde.

17. Luz raconte la « une » du nouveau numéro de « Charlie Hebdo ». [Luz tells the story of the new Charlie Hebdo cover]. Le Monde.

18. Tuttle B (2015) Historic Charlie Hebdo issue selling for $\$ 1100$ on eBay Time.

19. Piquard A (2015a) « Charlie Hebdo »: Riss devrait faire son retour lundi. [Charlie Hebdo: Riss should be back Monday]. Le Monde.

20. Paris G (2015) « Je me souviens du 11-September, il est normal que je vienne aujourd'hui ». [I remember September 11, it is normal that I came today]. Le Monde.

21. Lauer S (2015) New York rend hommage à « Charlie Hebdo ». [New York pays tribute to Charlie Hebdo]. Le Monde.

22. Attentat contre "Charlie Hebdo »: Solidarité international dans la lutte contre le "terrorisme." [Attack against Charlie Hebdo: International solidarity in the fight against "terrorism."] Le Monde.

23. "Charlie Hebdo » la carte des rassemblements d'hommages en France. [The maps of gatherings to pay tribute to Charlie Hebdo in France]. Le Monde.

24. Attentat contre « Charlie Hebdo »: Recueillement européen. [Attack against Charlie Hebdo: European moment of reflection]. Le Monde.
25. De Lima à Tirana, des centaines de "Je suis Charlie ». [From Lima to Tirana, hundreds of "I am Charlie."] Le Monde.

26. Hollywood est « Charlie » lors des Golden Globes. [Hollywood is "Charlie" during the Golden Globes]. Le Monde.

27. Colombani JM (2013) Nous sommes tous américains. [We are all American].

28. Appadurai A (1996) Modernity at large: Cultural dimensions of globalization. Minneapolis, MN: University of Minnesota Press.

29. Giddens A (1999) Runaway world: How globalization is reshaping our lives. London: Profile books.

30. Pieterse JN (2009) Globalization and Culture: Global Mélange. 2nd ed Lanham, MD: Rowman \& Littlefield Publishers.

31. Castells M (2000) The Rise of the Network Society: The Information Age: Economy, Society and Culture. Oxford, UK: Blackwell.

32. Tomlinson J (1999) Globalization and Culture. Chicago: University Of Chicago Press.

33. Anderson B (1991 [1983] ) Imagined communities: Reflections on the origin and spread of nationalism. London, UK: Verso.

34. Hegde R (2011) "Introduction." In R. Hedge (Ed.), Circuits of Visibility: Gender and Transnational Media Cultures (pp. 1-17). New York, NY: New York University Press.

35. Goldman D, Pagliery J (2015) Je suis Charlie becomes one of the most popular hashtags in Twitter's history. CNN.

36. Leloup D, Tuai M (2015) Sur les réseaux sociaux, \#Je suis Charlie, flic Ahmed, Franck... [On social media, \#Je suis Charlie, cop, Ahmed, Franck]. Le Monde.

37. \#JeSuisCharlie: sur Internet vague mondiale d'émotion après la tuerie de « Charlie Hebdo ». [\#JeSuisCharlie: on Internet worldwide wave of emotion after the Charlie Hebdo killings]. (2015, January 7). Le Monde.

38. Potet F (2015a) Chappatte: Depuis l'attentat de " Charlie Hebdo », on a franchit une "ligne dans le sang ». [Chappate: Since the Charlie Hebdo attack, we have crossed a "line in the blood"]. Le Monde.

39. Dessinateurs du monde entier, tous « Charlie ». [Cartoonists from around the globe, all “Charlie."] Le Monde.

40. En Egyple, au Sénégal ou à Jérusalem ... la « une » de « Charlie Hebdo » ne passe pas. [In Egypt, Senegal or Jerusalem, the Charlie Hebdo cover does not pass the test]. Le Monde.

41. Bouabib A (2015) "Charlie Hebdo ", le Maroc a raté le rendez vous de Paris. [Charlie Hebdo, Morocco missed the Paris rendezvous]. Le Monde.

42. Reese $S$ (2010) Journalism and globalization. Sociology Compass 4: $344-$ 353.

43. Appadurai A (2013) The future as cultural fact: Essays on the global condition. New York, NY: Verso.

44. Bennoune K (2016) The truth about Charlie: One year after the 7 January attacks. Open Democracy.

45. Jaxel-Truer P (2015) C'est quoi l'esprit « Charlie Hebdo »? [What is the Charlie Hebdo spirit?]. Le Monde.

46. Potet $\mathrm{F}(2015 \mathrm{~b})$ Les éditeurs de BD s'unissent pour un album-hommage à "Charlie Hebdo ». [BD publishers unite for a Charlie Hebdo tribute album]. Le Monde.

47. Maillard M (2015) Pour les lycéens caricaturistes, l'esprit "Charlie " demeure. [For high school caricaturists, the "Charlie" spirit is still alive]. Le Monde.

48. Après l'attaque contre "Charlie Hebdo », des manifestations spontanées dans toute la France. [After the Charlie Hebdo attack, spontaneous manifestations all over France]. Le Monde.

49. Courtois C (2015) A Bordeaux, les larmes et le choc après l'attaque de «Charlie Hebdo ». [In Bordeaux, tears and shock after the Charlie Hebdo attack.] Le Monde.

50. Fabre C (2015) Le père, le fils et « Charlie Hebdo ». [The father, the son, and Charlie Hebdo]. Le Monde. 
51. Dupont G, Chambraud C (2015) « Charlie Hebdo »: Chez les musulmans, la peur de l'amalgame. [Charlie Hebdo: Among Muslims, fear of amalgamation]. Le Monde.

52. Battaglia M, Floc'h B (2015) A Saint-Denis, collégiens et lycéens ne sont pas tous "Charlie». [In Saint-Denis middle school and high school students are not all "Charlie."] Le Monde.

53. Nunès $E$ (2015) Dans les collèges et lycées, le soutien à « Charlie Hebdo » loin de faire l'unanimité. [In middle and high schools, support for Charlie Hebdo is far from unanimous]. Le Monde.

54. Piquard A (2015b) II faut écouter ceux qui disent « je ne suis pas Charlie. » [We must listen to those who say "I am not Charlie".] Le Monde.

55. Zappi S (2015, January 15). La banlieue tiraillée entre "Charlie » et pas Charlie ». [The banlieue torn between "Charlie" and "not Charlie"]. Le Monde.

56. El Rhazoui Z (2015) Zineb de « Charlie Hebdo »: "Il arrivait qu'on dise aux collèges, 'je vous aime' ». [Zineb from Charlie Hebdo: "We sometimes told our colleagues, 'I love you.'”]. Le Monde.

57. Piquard $\mathrm{A}$ (2015c) Tensions à «Charlie Hebdo » sur le mode de gestion du journal. [Tensions at Charlie Hebdo over the handling of the newspaper] Le Monde.

58. Piquard A (2015d) "Charlie Hebdo »: Zineb El Rhazoui « scandalisée " de sa mise à pied. [Charlie Hebdo: Zineb El Rhazoui“scandalized” by her suspension]. Le Monde.

59. Piquard A (2015e) La vie à "Charlie » n'a jamais été un long fleuve tranquille. [Life at Charlie was never easy]. Le Monde.

60. Luz annonce son départ de "Charlie Hebdo ». [Luz announces his departure from Charlie Hebdo]. Le Monde.

61. Lichfield J "Charlie Hebdo" loses star cartoonist and writer as infighting takes its toll on magazine. Independent

62. Stam R, Shohat E (2009) Transnationalizing Comparison: The Uses and Abuses of Cross- Cultural Analogy. New Literary History 40: 473-499.

63. García Canclini N (2014) Imagined Globalization. Duke University Press.

64. Chambraud C (2015) Aux rencontres de I'UOIF, conflit de générations après "Charlie ». [At the UOIF meeting, conflict of generations after "Charlie"]. Le Monde.

65. Courtois G (2015) Inquiète, la France de l'après-Charlie est tentée par le repli. [Worried, post-Charlie France leans toward withdrawal]. Le Monde.

66. « Charlie Hebdo »: La stratégie du Front National est-elle un échec?[Charlie Hebdo is the National Front's strategy a failure?] (2015, January 19). Le Monde. [video]

67. Jérome B (2015) « Charlie Hebdo » : à Paris, la crainte de « la stigmatisation " des musulmans. [Charlie Hebdo: In Paris, fear of stigmatization of Muslims]. Le Monde.

68. Dubin L (2015) Fixons les contours de la liberté avant de réprimer ceux qui ne sont pas «Charlie ». [Let us establish the limits of freedom before condemning those who are not "Charlie."] Le Monde.

69. Manuel Valls évoque « un apartheid territorial, social, ethnique » en France [Manuel Valls speaks of a "territorial, social, ethnic apartheid" in France.] (2015). Le Monde.

70. Said EW (1978) Orientalism, New York: Pantheon Books.

71. Said EW (1985) Orientalism reconsidered, Race \& Class 27(2), pp. 1-15.

72. Said EW (1987) Covering Islam: How the media and the experts determine how we see the rest of the world, New York: Vintage Books.

73. Cunningham V (1983) Xenophobia for beginners. Times Literary Supplement 4028: 1316.

74. Rösch F (2014) 'Hooray! Hooray! The End of the World has been Postponed!' Politics of Peace in the Adventures of Tintin? Politics 34: 225236.

75. Dunnett $\mathrm{O}$ (2009) Identity and geopolitics in the Adventures of Tintin. Social \& Cultural Geography 10: 583-598.

76. Lazimi C (2015) Astérix est-il raciste? [Is Astérix Racist?] L’Express.
77. Darling-Wolf F (1998) White bodies and feminist dilemmas: On the complexity of positionality. Journal of Communication Inquiry 22: 410-425.

78. Alcoff L (1995) The problem of speaking for others." In J. Roof and R. Wiegman (Eds.), Who can speak: Authority and critical identity (pp. 97119). Urbana, IL: University of Illinois Press.

79. Chow R (1993) Writing diaspora: Tactics of intervention in Cultural Studies. Bloomington, IN: Indiana University Press.

80. Hook B (1994) Outlaw culture: Resisting representation. New York, NY: Routledge Kegan Paul.

81. Spivak GC (1988) "Can the Subaltern Speak?" In C. Nelson and L. Grossberg (Eds.), Marxism and the Interpretation of Culture (pp. 271-313). Urbana, IL: University of Illinois Press.

82. Lutkehaus N, Cool J (1999) "Paradigms lost and found: The "crisis of representation' and visual anthropology." In J. M. Gaines and M. Renov (Eds.), Collecting visible evidence (pp. 434-454).Minneapolis, MN: University of Minnesota Press.

83. Morris R (2010) Can the subaltern speak?: Reflections on the history of an idea. New York, NY: Columbia University Press. 